\title{
Review: Handout Digital pada Masa Pandemi dalam Pembelajaran Kimia
}

\author{
Yoriska Noventi Putri
}

Pendidikan Kimia, Universitas Negeri Surabaya

Email: yoriska.17030194023@mhs.unesa.ac.id

Rinaningsih Rinaningsih

Pendidikan Kimia, Universitas Negeri Surabaya

Email: rinaningsih@unesa.ac.id

(Diterima: 2-Januari-2021; direvisi: 3-Februari-2021; dipublikasikan: 20-Maret-2021)

\begin{abstract}
The aim of this article is to examine the effects of influences during a pandemic period to improve learning outcomes in chemical materials. The method used is meta-analysis by summarizing, analyzing, and analyzing data from the literature and processed statistically. During the pandemic, teachers must be creative in learning because the learning process is carried out in a bold manner. As facilitators, teachers can facilitate students by providing digital handouts that can be accessed more easily without the internet. In addition, the use of handouts has a strong influence on improving student learning outcomes. The increase in student learning outcomes can be observed through paired sample statistical tests and the effect size of learning outcomes between before use and use of handouts. The use of handouts as an alternative to teaching materials can improve learning outcomes by $38.6 \%$. This shows that digital material can be used as an alternative to chemical teaching materials during the pandemic.
\end{abstract}

Keywords: Digital Handout; Learning Media; Covid-19 Pandemic; Chemistry Learning.

\section{PENDAHULUAN}

Pandemi

Covid-19

telah menyebabkan terjadinya perubahan tatanan pendidikan di dunia. Pandemi tersebut menyebabkan tejadinya transisi secara cepat dari pertemuan tatap muka menjadi pertemuan secara online (daring) [35]. Pembelajaran secara online (daring) memiliki tantangan yang besar bagi siswa dan guru, salah satunya yaitu sulitnya akses internet yang menyebabkan siswa kesulitan hadir selama proses pembelajaran berlangsung. Dengan adanya permasalahan tersebut siswa menjadi kesulitan memahami materi, terutama pelajaran yang membutuhkan pemahaman tinggi [36].

Kimia merupakan salah satu mata pelajaran yang dianggap sulit bagi siswa sehingga menurunkan minat belajar siswa terhadap pelajaran kimia. Penurunan minat siswa terhadap kimia mengakibatkan siswa kesulitan dalam memahami materi tersebut. Terdapat beberapa penyebab mengapa kimia dianggap pelajaran yang sulit, yakni penggunaan metode pembelajaran yang kurang tepat dan penyajian materi yang kurang menarik menyebabkan siswa menjadi cepat merasa bosan [37]. Terutama dimasa pandemi, siswa melakukan proses pembelajaran dirumah tanpa pengawasan guru [35]; [36]; [41]; [42]; [43].

Selama pandemi berlangsung, guru melakukan proses pembelajaran jarak jauh dengan aplikasi digital seperti Google Classroom, ZOOM, Moodle, Discord, dll [18]; [41]; [42]. Proses pembelajaran yang diandalkan oleh guru yakni model pembelajaran ceramah, dimana guru menjelaskan materi sedangkan siswa duduk dan mendengarka. Proses pembelajaran ini bersifat teacher center dan tidak efektif digunakan apabila materi yang diberikan 
terlalu banyak. Proses pembelajaran ini mengakibatkan siswa kesulitan dalam memahami materi, sehingga hasil belajar menurun dan tidak tercapainya kompetensi belajar [38].

Pembelajaran yang bersifat teacher center di Indonesia mulai berkurang setelah diterapkannya kurikulum terbaru yang berbasis student center [38]. Pembelajaran student center menuntut keaktifan siswa dalam proses belajar dan guru bertindak sebagai fasilitator. Guru memegang peran penting dalam mempersiapkan bahan ajar serta fasilitas pendukung lain untuk siswa terutama di masa pandemi Covid-19 [53]; [54]. Salah satu fasilitas yang dapat digunakan oleh guru untuk mendukung proses pembelajaran siswa yaitu handout [1]; [2]; [3]; [4]; [5]; [6]; [7]; [8]; [9]; [10]; [11]; [12]; [13]; [14]; [15]; [16]; [17]; [18]; [19]; [20]; [21]; [22]; [23]; [24]; [25]; [26]; [27]; [28]; [29]; [30]; [31]; [32]; [33]; [34]; [44].

Handout disediakan oleh guru sebagai sumber belajar yang berisi konsep penting dari suatu materi pembelajaran [18]; [30]; [31]; [32]; [33]; [44]. Handout layak digunakan sebagai bahan ajar apabila memenuhi kriteria valid, praktis, dan efektif [3]; [6]; [19]; [20]; [21]; [22]; [23]; [24]; [25]; [26]. Handout dikatakan valid apabila didesain berdasarkan state of the art knowledge dan komponen isi saling terkait satu sama lain [6]. Kepraktisan ditunjukkan berdasarkan kemudahan pemakaian handout oleh guru dan siswa, sedangkan keefektifan diketahui berdasarkan seberapa besar pengaruh handout bagi guru maupun siswa [6]; [21]; [22]; [23]. Besar atau kecilnya pengaruh handout didasarkan pada kemampuan guru dalam membuat handout itu sendiri [22]. Handout dianggap memiliki pengaruh yang signifikan terhadap siswa karena mampu meningkatkan prestasi belajar dan melatih keterampilan siswa handout [1]; [2]; [3]; [4]; [5]; [6]; [7]; [8]; [9]; [10]; [11]; [12]; [13]; [14]; [15]; [16]; [17]; [18]; [19]; [44].

Penggunaan handout dapat melatih keterampilan siswa karena menuntut keaktifan siswa selama proses pembelajaran berlangsung [1]; [5]; [18]; [25]; [26]; [27]; [28]; [29]. Keterampilan yang dianggap penting untuk dilatihkan kepada siswa yaitu keterampilan abad 21, sesuai dengan kurikulum terbaru [8]; [11]; [17]; [24]. Selain melatihkan keterampilan, handout memiliki pengaruh yang besar terhadap prestasi belajar. Hal ini ditunjukkan dengan adanya peningkatan pada pemahaman konsep, peningkatan hasil belajar, dan ketercapaian kompetensi belajar. Peningkatan prestasi siswa dapat diketahui secara kuantitatif berdasarkan hasil uji statistik kenaikan hasil belajar handout [1]; [2]; [3]; [4]; [5]; [6]; [7]; [8]; [9]; [10]; [11]; [12]; [13]; [14]; [15]; [16]; [17]; [18]; [19].

Pandemi Covid-19 menuntut guru untuk lebih kreatif dalam proses pembelajaran, terutama penggunaan media digital [35]; [36]. Handout digital dapat digunakan sebagai pengganti handout, karena dapat diakses melalui media digital seperti Handphone dan laptop tanpa membutuhkan akses internet yang berkelanjutan [18]. Artikel review ini dibuat untuk mengetahui pengaruh penggunaan handout digital selama masa pandemi dalam meningkatkan hasil belajar pada materi kimia.

\section{METODE}

Penulisan artikel review ini menggunakan teknik meta analisis data. Teknik meta analisis digunakan untuk meninjau penelitian dimana data dari setiap penelitan yang seragam digabungkan secara satistik. Metode ini dilakukan dengan cara merangkum, merewiew, dan menganalisis data dari literatur dan diolah secara statistik [39]. Jenis metode yang digunakan yaitu Study Effect Size yang berfungsi untuk mengetahui besar keefektifan dari penggunaan handout. Pengukuran Effect Size menggunakan rumus berikut.

$$
\text { Effect Size = }
$$

Posttest average score-pretest average score

standart deviation 
Uji statistik perbandingan hasil literatur penelitian yang relevan sebanyak empat artikel penelitian yaitu Dyah Pujiastuti, Ashadi, \& Sri Mulyani (2018) [25]; Sri Adelila Sari, Jasmidi, Agus Kembaren, \& Ajat Sudrajat (2018) [8]; Nitema Gulo, Julia Maulina, \& Lisa Ariyanti Pohan (2018) [9]; Muhammad Luqman, Budi Utami \& Ashadi (2016) [10].

\section{HASIL DAN PEMBAHASAN}

Artikel ini dibuat untuk mengetahui pengaruh penggunaan handout digital selama masa pandemi dalam meningkatkan hasil belajar pada materi kimia dengan cara membandingkan beberapa studi literatur penelitian. Handout merupakan bahan ajar yang berisi konsep penting dan digunakan untuk membantu siswa selama proses pembelajaran berlangsung [18]; [30]; [31]; [32]. Handout memiliki prinsip yang sama dengan bahan ajar lain yakni relevansi, konsistensi, dan kecukupan. Prinsip relevansi artinya materi harus berkaitan dengan pencapaian kompentesi dasar, sedangkan prinsip kompetensi berkaitan dengan isi materi memenuhi standart kompetensi. Prinsip kecukupan artinya bahan ajar harus membantu siswa dalam mencapai kompetensi yang telah ditentukan [41]. Sebagai salah satu fasilitas yang disediakan oleh guru, handout memiliki beberapa kelebihan. Salah satu kelebihan handout yaitu meningkatkan hasil belajar siswa handout [1]; [2]; [3]; [4]; [5]; [6]; [7]; [8]; [9]; [10]; [11]; [12]; [13]; [14]; [15]; [16]; [17]; [18]; [19].

Pengaruh penggunaan handout sebagai alternatif untuk menngkatkan hasil belajar dibuktikan dengan uji statistik. Uji statistik tersebut diperoleh dengan membandingkan 4 artikel yang diuji statistik, diantaranya yaitu Dyah Pujiastuti, Ashadi, \& Sri Mulyani (2018) [2]; Sri Adelila Sari, Jasmidi, Agus Kembaren, \& Ajat Sudrajat (2018) [8]; Nitema Gulo, Julia Maulina, \& Lisa Ariyanti Pohan (2018) [9]; Muhammad Luqman, Budi Utami \& Ashadi (2016) [10].

Hasil analisis artikel yang diuji statistik dipaparkan secara deskriptif kualitatif dan kuantitatif. Persentase pengaruh sebelum dan sesudah penggunaan handout terhadap hasil belajar siswa dalam pembelajaran kimia dapat dilihat pada Tabel 1.

Tabel 1. Persentase Hasil Belajar Siswa Sebelum dan Sesudah Penggunaan Handout

\begin{tabular}{|c|c|c|c|}
\hline \multirow[b]{2}{*}{ Penulis } & \multicolumn{3}{|c|}{ Persentase Hasil Belajar (\%) } \\
\hline & $\begin{array}{l}\text { Sebelum } \\
\text { Penggunaan }\end{array}$ & $\begin{array}{c}\text { Sesudah } \\
\text { Penggunaan }\end{array}$ & Peningkatan \\
\hline $\begin{array}{l}\text { Dyah Pujiastuti, Ashadi, \& Sri } \\
\text { Mulyani (2018) }\end{array}$ & 31,7 & 85,7 & 54,0 \\
\hline $\begin{array}{l}\text { Sri Adelila Sari, Jasmidi, Agus } \\
\text { Kembaren, \& Ajat Sudrajat (2018) }\end{array}$ & 70,8 & 97,0 & 26,2 \\
\hline $\begin{array}{l}\text { Nitema Gulo, Julia Maulina, \& Lisa } \\
\text { Ariyanti Pohan (2018) }\end{array}$ & 33,6 & 73,8 & 40,2 \\
\hline $\begin{array}{l}\text { Muhammad Luqman, Budi Utami \& } \\
\text { Ashadi (2016) }\end{array}$ & 43,0 & 77,0 & 34,0 \\
\hline Rata-rata & 44,7 & 83,3 & 38,6 \\
\hline $\begin{array}{l}\text { Berdasarkan Tabel 1, persentase rata- } \\
\text { rata hasil belajar siswa sebelum penggunaan } \\
\text { handout sebesar } 44,7 \% \text { dan sesudah } \\
\text { penggunaan handout sebesar } 83,3 \% \text {. Hal } \\
\text { tersebut menunjukkan terjadinya } \\
\text { peningkatan rata-rata hasil belajar siswa }\end{array}$ & \multicolumn{3}{|c|}{$\begin{array}{l}\text { sebesar } 38,6 \% \text {. Berdasarkan uraian tersebut } \\
\text { maka dapat dikatakan handout mamp } \\
\text { membantu siswa untuk meningkatkan hasi } \\
\text { belajar. Peningkatan hasil belajar siswa } \\
\text { tersebut dipengaruhi oleh peningkatar } \\
\text { aktifitas belajar siswa secara individual [1] }\end{array}$} \\
\hline
\end{tabular}


[5]; [18]; [25]; [26]; [27]; [28]; [29]. Pemberian handout kepada setiap siswa mengakibatkan siswa lebih termotivasi dalam menggali informasi, sehingga pengetahuan siswa juga meningkat [10]; [31]; [32]. Kemajuan pembelajaran dari penggunaan handout sebagai alternative bahan ajar dapat dilihat berdasarkan analisis uji statistik tipe paired sample dan didapatkan hasil uji statistik yang dapat diamati pada Tabel 2, Tabel 3, dan Tabel 4.

Tabel 2. Paired Samples Statistics

\begin{tabular}{cccccc}
\hline \multicolumn{5}{c}{ Paired Samples Statistics } \\
\cline { 3 - 6 } & Mean & $N$ & $\begin{array}{c}\text { Std. } \\
\text { Deviation }\end{array}$ & Std. Error Mean \\
\hline \multirow{2}{*}{ Pair 1 } & Sebelum & 44.7750 & 4 & 18.03966 & 9.01983 \\
\cline { 2 - 6 } & Sesudah & 83.3750 & 4 & 10.38216 & 5.19108 \\
\hline
\end{tabular}

Tabel 3. Paired Samples Correlation Paired Samples Correlations

\begin{tabular}{ccccc} 
& & $\mathrm{N}$ & Correlation & Sig. \\
\hline Pair 1 & Sebelum \& Sesudah & 4 & .788 & .212 \\
\hline
\end{tabular}

Tabel 4. Paired Samples Test

\begin{tabular}{|c|c|c|c|c|c|c|c|c|}
\hline \multicolumn{9}{|c|}{ Paired Samples Test } \\
\hline & \multicolumn{5}{|c|}{ Paired Differences } & \multirow{3}{*}{$\mathrm{t}$} & \multirow{3}{*}{ df } & \multirow{3}{*}{ Sig. (2-tailed $)$} \\
\hline & \multirow[t]{2}{*}{ Mean } & \multirow[t]{2}{*}{$\begin{array}{c}\text { Std. } \\
\text { Deviation }\end{array}$} & \multirow[t]{2}{*}{$\begin{array}{c}\text { Std. Error } \\
\text { Mean }\end{array}$} & \multicolumn{2}{|c|}{$\begin{array}{l}\text { 95\% Confidence } \\
\text { Interval of the } \\
\text { Difference }\end{array}$} & & & \\
\hline & & & & Lower & Upper & & & \\
\hline 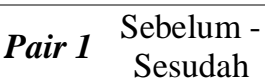 & 38.60000 & 11.75642 & 5.87821 & $\begin{array}{c}- \\
57.30708\end{array}$ & $\begin{array}{c}- \\
19.89292\end{array}$ & $-\overline{-}$ & 3 & .007 \\
\hline
\end{tabular}

Tabel 2 menunjukkan uji statistik handout terhadap hasil belajar siswa dari beberapa penelitian dengan rata-rata hasil belajar sebelum penggunaan handout sebesar 44,7750 dan rata-rata hasil belajar sesudah penggunaan handout mengalami peningkatan menjadi 83,3750. Pada Tabel 3 menunjukkan angka korelasi nilai rata-rata sebelum dan sesudah penggunaan handout yaitu sebesar 0,788 . Nilai signifikan pada Tabel 3 sebesar $(0,212)>\alpha(0,05)$ yang menunjukkan tidak terdapat korelasi antara sebelum penggunaan handout maupun setelah penggunaan handout.

Uji hipotesis dapat ditunjukkan apabila $\mathrm{H}_{0}=$ tidak terdapat perbedaan yang signifikan antara sebelum penggunaan handout dan sesudah penggunaan handout, sedangkan $\mathrm{H}_{1}=$ terdapat perbedaan yang signifikan antara sebelum penggunaan handout dan sesudah penggunaan handout.
Pencarian nilai $\mathrm{T}$ tabel menggunakan Tabel T statistic dengan t 0,975 dan $\mathrm{dk} 3$ didapatkan nilai $\mathrm{T}$ tabel sebesar 3,18245. Dengan demikian, diperoleh hasil $\mathrm{T}$ hitung $(-6.567)<\mathrm{T}$ tabel $(3,18245)$ sehingga $\mathrm{H}_{1}$ diterima dan $\mathrm{H}_{0}$ ditolak, maka terdapat perbedaan yang signifikan hasil belajar siswa antara sebelum penggunaan handout dan sesudah penggunaan handout. Tabel 4 menunjukkan uji statistik handout terhadap hasil belajar siswa dari beberapa penelitian dengan rata-rata hasil belajar sebelum dan sesudah penggunaan handout sebesar 38.60000. Pada Tabel 4 didapatkan standar deviasi sebesar 11.75642 sehingga dapat di ketahui pengaruh penggunaan handout terhadap hasil belajar siswa menggunakan effect size.

$$
\text { Effect size }=\frac{38.60000}{11.75642}=3,2833
$$


Berdasarkan perhitungan diatas, maka didapatkan effect size sebesar 3,2833 > 1,0 sehingga handout memiliki pengaruh yang kuat terhadap peningkatan hasil belajar siswa. Dengan kelebihan handout sebagai salah satu fasilitas yang dapat meningkatkan hasil belajar, penggunaan handout dapat diterapkan bersamaan dengan media digital. Penggunaan handout yang dapat diakses dalam media digital seperti Handphone dan Laptop disebut dengan handout digital [18].

Devangga (2020) dalam
penelitiannya menyatakan bahwa handout digital mampu menunjang pembelajaran di luar kelas. Handout digital dapat diaplikasikan apabila siswa kesulitan dalam memahami bahan ajar yang disajikan dengan tatap muka [18]. Oleh karena itu, handout digital dapat digunakan sebagai alternatif bahan ajar dalam sistem pembelajaran daring (pembelajaran online).

Proses pembelajaran dimasa pandemi covid-19 berbeda dengan pembelajaran pada umumnya. Pandemi tersebut menyebabkan tejadinya transisi secara cepat dari pertemuan tatap muka menjadi pertemuan secara online (daring) [35]; [42]; [43]. Pembelajaran daring merupakan pembelajaran yang berbasis pada penggunaan platform internet dan tidak dilakukan secara tatap muka. Pembelajaran ini memiliki kelebihan dan kekurangan. Kelebihan pembelajaran daring yakni pembelajaran dapat dilakukan dimanapun asalkan memiliki media digital dan koneksi internet yang memadai. Kelemahan dari pembelajaran ini adalah sulitnya siswa mencari koneksi yang bagus karena setiap siswa memiliki situasi yang berbeda [41].

Selama pandemi berlangsung, guru dituntut untuk lebih kreatif selama proses pembelajaran karena besarnya tantangan yang dimiliki guru dan siswa. Salah satu tantangan tersebut adalah sulitnya siswa mengakses jaringan internet, dimana selama pandemi semua pembelajaran dilakukan secara daring dan membutuhkan akses internet yang lancar [36]. Oleh karena itulah dibutuhkan terobosan baru seperti handout digital yang dapat digunakan tanpa akses internet lancar dan berkelanjutan [18]. Penggunaan handout digital tidak membutuhkan akses internet yang lancar dan dapat dipergunakan kapanpun dan dimanapun selama memiliki media digital. Dengan diterapkannya handout digital, maka dapat menutupi kelemahan dari pembelajaran daring. Didukung dengan analisis uji statistik dari keempat literatur, penggunaan handout digital secara daring mampu meningkatkan hasil belajar siswa meskipun pembelajaran dilakukan di luar kelas. Dengan demikian, siswa lebih mudah dalam mengkakses proses pembelajaran dan mudah memahami materi sehingga hasil belajar tetap mengalami peningkatan.

\section{SIMPULAN DAN SARAN}

Berdasarkan hasil penelitian, maka kesimpulan dari penelitian ini adalah penggunaan handout digital sebagai alternatif bahan ajar dapat meningkatkan hasil belajar materi kimia dalam masa pandemi. Hal tersebut didukung dengan hasil uji size effect yang menunjukkan bahwa penggunaan handout memiliki pengaruh yang kuat terhadap peningkatan hasil belajar. Berdasarkan uji statistik dari keempat literatur, didapatkan peningkatan hasil belajar antara sebelum penggunaan dan sesudah penggunaan handout sebesar $38,6 \%$. Hal tersebut menunjukkan bahwa terjadi peningkatan selama penggunaan handout. Dengan demikian, handout digital dapat dipertimbangkan sebagai salah satu alternatif bahan ajar yang dapat digunakan dalam pembelajaran kimia selama pandemi Covid-19 berlangsung.

\section{DAFTAR RUJUKAN}

Adelila S, S., Jasmidi, J., Kembaren, A., \& Sudrajat, A. (2018). The Development Of Handout Based On Guided Note Taking To Improve The Quality Of Analitycal Chemistry Learning People. International Journal of Social Sciences. 4(3), 720734.

Adhia, H. (2017). Studi Penggunaan Handout dalam Model 
Pembelajaraan Kooperatif Tipe Artikulasi terhadap Pembelajaran Matematika Siswa Kelas X Jurusan Administrasi Perkantoran (Ap) SMKN 1 Kota Solok. Lemma. 4(1).

Aini, E. P., Masyur, R., \& Komaruddin. (2018). Handout Matematika berbantuan Etnomatematika Berbasis Budaya Lokal. Jurnal Matematika. 1(1), 73-79.

Ariyanti, D., Utomo, S. B., \& Mulyani, B. (2016). Peningkatan Aktivitas Dan Prestasi Belajar Siswa Dengan Menggunakan Pembelajaran Team Assisted Individualization (Tai) Berbantuan Handout Dan Eksperimen Pada Materi Kelarutan Dan Hasil Kali Kelarutan Kelas XI IPA 3 SMA Negeri Gondangrejo. Jurnal Pendidikan Kimia Universitas Sebelas Maret. 5(4), 91-97.

Azizah, H. P., Utami, B., \& Haryono. (2017). Penerapan Model Pembelajaran Teams Assisted Individualized (Tai) Dilengkapi Handout Berbasis Model Latihan Untuk Meningkatkan Kerjasama Dan Prestasi Belajar Siswa Pada Materi Pokok Hidrolisis Kelas XI IPA Semester Genap SMA Muhammadiyah 1 Karanganyar. Jurnal Pendidikan Kimia Universitas Sebelas Maret. 6(1), 31-38.

Cahyanto, M. A. S., Utomo, S. B., \& Yamtinah, S. (2016). Penggunaan Model Pembelajaran Cooperative Problem Solving (Cps) Dilengkapi Handout Untuk Meningkatkan Kemampuan Berpikir Kritis Dan Prestasi Belajar Siswa Materi Termokimia Kelas XI IPA Semester Ganjil SMA N 3 Boyolali Tahun Pelajaran 2015/2016. Jurnal Pendidikan Kimia Universitas Sebelas Maret. 4(5), 43-50.

Devangga, P. A. P., \& Norida C. S. (2020). Pengembangan Media Pembelajaran Handout Digital Berbasis Android. Jurnal Pendidikan Ekonomi Undiksha. 12(1), 15-28.
Elizabeth M. S., \& Ceff, J. (2015). REVIEW Note-taking and Handouts in The Digital Age. American Journal of Pharmaceutical Education. 79(7), 07.

Erlinda, N. (2016). The Application of Inquiry Learning Methods with Handout: Impact on Student Learning Outcomes on Physics at SMAN 1 Batang Anai Padang Pariaman. Jurnal Ilmiah Pendidikan Fisika Al-Biruni. 5(2), 225-233.

Farida, I., Risa, R., Riri, A., \& Imelda, H. (2020). Pembelajaran Kimia Sistem Daring di Masa Pandemi Covid-19 Bagi Generasi Z. Karya Tulis Ilmiah (KTI) Masa Work From Home (WFH) Covid-19. 1-11.

Fatma, Holiwarni, B., \& Susilawati. (2016). Pengembangan Handout Bermuatan Kecerdasan Komprehensif untuk Materi Laju Reaksi pada Kelas XI SMA. Jurnal Online Mahasiswa (JOM) Bidang Keguruan dan Ilmu Pendidikan. 2(3), 1-11.

Fontana, T. M. (2020). Gamification of ChemDraw during the COVID-19 Pandemic: Investigating How a Serious, Educational-Game Tournament (Molecule Madness) Impacts Student Wellness and Organic Chemistry Skills while Distance Learning. J. Chem. Educ. 97(9), 3358-3368.

Gulo, N., Maulina, J., \& Pohan, L. A. (2018). Penerapan Learning Start with a Question Menggunakan Media Handout dan Peta Konsep pada Materi Hidrolisis Garam di SMA PRAYATNA Medan. Journal of Chemistry, Education, and Science. 2(1), 22-35.

Habibati, H., Nazar, M., \& Septiani, P. D. (2019). Pengembangan Handout Berbasis Literasi Sains Pada Materi Larutan Elektrolit dan Nonelektrolit. JIPI (Jurnal IPA dan Pembelajaran IPA). 1(3), 36-41.

Haji, A. G., Safriana, \& Safitri, R,. (2015). The Use of Problem Based Learning 
to Increase Students' Learning Independent and to Investigate Students' Concept Understanding on Rotational Dynamic at Students of SMA Negeri 4 Banda Aceh. Jurnal Pendidikan IPA Indonesia. 4(1), 6772.

Hasanah, U., Gummah, S., \& Herayanti, L. (2018). Perbedaan Hasil Kemampuan Berpikir Kritis dan Berpikir Kreatif Siswa Menggunakan Handout Berbasis Pemecahan Masalah. Prisma Sains. 6(9), 38-45.

Hia, E. D. S. P., Maulina, J., \& Pohan, L. A. (2018). Penerapan Model Pembelajaran Problem Based Llearning Menggunakan Handout dan Modul pada Materi Stoikiometri Larutan di SMA Nurul Amaliyah Deli Serdang. Journal of Chemistry, Education, and Science. 1(2), 1-13.

Humaira, H., Saputro, S., \& Setyowati, W. A. E. (2019). Studi Komparasi Metode Pembelajaran Kooperatif Student Teams Achievement Division (STAD) dan Numbered Head Together (NHT) Berbantuan Media Handout terhadap Prestasi Belajar Siswa Materi Sistem Periodik Unsur Kelas X SMA Negeri 2 Sukoharjo tahun pelajaran 2015/2016. Jurnal Pendidikan Kimia. 2(8), 299-305.

Islamic, A. R., Soekardjo, J. S., \& Nurhayati, N.D. (2016). Penerapan Metode Pembelajaran Team Assisted Individualization (TAI) Dilengkapi Handout untuk Meningkatkan Prestasi Belajar dan Interaksi Sosial Siswa pada Materi Pokok Tata Nama Senyawa Kimia dan Persmn Reaksi Kimia Kelas X SMA Negeri Gondangrejo Karanganyar Tahun Pelajaran 2013/2014. Jurnal Pendidikan Kimia (JPK). 2(5), 6874.

Korniawati, A., Kusumo, E., \& Susilaningsih, E. (2016). Validitas Chemistry Handout Sebagai Inovasi Bahan Ajar Stoikiometri Berstrategi
PBS Bervisi Sets. Jurnal Inovasi Pendidikan Kimia. 1(10), 1629-1640. Luqman, M., Utami, B., \& Ashadi. (2016). Penerapan Model Pembelajaran Team Assisted Individualization (Tai) Disertai Handout Untuk Meningkatkan Motivasi, Keaktifan, Dan Prestasi Belajar Siswa Pada Materi Pokok Kelarutan Dan Hasil Kali Kelarutan Kelas XI IPA 4 SMA Muhammadiyah 1 Karanganyar. Jurnal Pendidikan Kimia Universitas Sebelas Maret. 5(4), 26-33.

Muliawati, E. D., Saputro, S., \& Raharjo, S. B. (2016). Pengembangan Handout Berbasis Team Assisted Individualization (TAI) untuk Meningkatkan Prestasi Belajar Siswa pada Materi Pembuatan Etanol Skala Laboratorium SMK Kimia Industri. Journal Inkuiri. 1(5), 37-44.

Pane, P., \& Muhammad, D. D. (2017). Belajar dan Pembelajaran. Jurnal Kajian Ilmu-ilmu Keislaman. 3(2).

Prilini, Desi F., Salam, U., \& Wardah. (2017). Developing Pop Up Handouts AS Reading Materials In Teaching Narrative Text. Jurnal Pendidikan dan Pembelajaran Untan. 6(2).

Pujiastuti, D., Ashadi, \& Mulyani, S. (2018). Pengembangan Handout Kimia Berbasis Inkuiri Terbimbing Dilengkapi Media Grafis pada Materi Ikatan Kimia MA. FKIP ePROCEEDING. 1(3), 305-311.

Purba, D. N., Damanik, M., Silaban, S., \& Simatupang, L. (2018). The difference of student's activities and learning outcome with problem based learning using macromedia flash and handout. Jurnal Pendidikan Kimia. 3(10), 403-408.

Rinaningsih. 2019. Pengembangan Model Perkuliahan Sorogan-Bandongan dalam Kimia Organik dan Dampaknya Pada Penguasaan Konsep, Tanggung Jawab, Kemandirian, dan Keterbukaan. Disertasi tidak dipublikasikan. 
Bandung: Universitas Pendidikan Indonesia.

Rodney A. T., \& Swapnil L. S. (2020). An International Perspective: Teaching Chemistry and Engaging Students Daring the COVID-19 Pandemic. $J$. Chem. Educ. 97(9), 3318-3321.

Santoso, F. L. (2017). Keefektifan Perangkat Pembelajaran Inkuiri Berbasis Metode Pictorial Riddle pada Materi Zat dan Karakteristiknya. Pensa: Jurnal Pendidikan Sains. 5(3).

Sari, S. A., Jasmidi, Kembaren, A., \& Sudrajat, A. (2018). The Impacts of Chemopoly-Edutainment to Learning Activities and Responses. Journal of Education and Learning. 12(2), 311318.

Shofwunnada, Nirwana, R. R., \& Hakim, F. (2018). The Development of Chemistry Handout Based On Unity Of Scienes Principles for the Chapter of Acid and Base Materials. Unnes Science Education Journal. 7(1), 6975.

Sugiyono. 2016. Metode Penelitian Kuantitatif, Kualitatif, dan Kombinasi. Bandung: alfabeta.

Sulatri, S., Nazar, M., Adiska, D. N. (2018). Pengembangan Hand-Out Konsep Larutan Berintegrasi Nilai Religi Untuk Meningkatkan Minat Belajar Siswa SMA Pada Pondok Pesantren Terpadu. Jurnal Pendidikan Sains Indonesia (Indonesian Journal of Science Education). 2(6), 95-100.

Sunarti, S. (2017). Penerapan Pembelajaran Menggunakan Hand Out dan Peta Konsep untuk Meningkatkan Aktivitas dan Hasil Belajar Siswa. Prisma Sains. 5(1), 8-14.

Sunasee, R. (2020). Challenges of Teaching Organic Chemistry during COVID19 Pandemic at a Primarily Undergraduate Institution. J. Chem. Educ. 97(9), 3176-3181.

Syafriani, D., \& Sisca J. (2019). Perbedaan Hasil Belajar dan Kemampuan Berpikir Kritis Siswa Yang Diajar Dengan Menggunakan Media
Handout Dan Power Point Pada Materi Larutan Penyangga. SEJ (School Education Journal). 9(3), 248-256.

Syahrowardi, S., \& Permana, A. H. (2016).

Desain Handout Multimedia

Menggunakan 3D Pageflip

Professional untuk Media

Pembelajaran pada Sistem Android.

Jurnal Penelitian \& Pengembangan Pendidikan Fisika. 2(1), 89-96.

Ulya, R., Sari, S. A., \& Ismayani, A. (2016). Pengembangan Handout Berbasis Guided Note Taking Pada Materi Koloid Kelas XI MAN Banda Aceh 1Tahun Pelajaran 2015/2016. Jurnal Ilmiah Mahasiswa Pendidikan Kimia (JIMPK). 4(1), 115-124.

Wati, L., \& Yuni F. (2017). Desain Bahan Ajar Berupa Handout Berbasis Inkuiri Terbimbing pada Pembelajaran Kimia Materi Hidrokarbon. Jurnal Konfigurasi. 2(1), 219-224.

Wati, M. (2015). Rancangan Hand Out Berbasis Peta Konseppada Materi Alat Indera Untuk Siswa Sekolah Menengah Pertama. Jurnal BioConcetta. 1(1), 32-44.

Winangun, I M. A., \& STAHN M. K. Singaraja. (2020). Perspektif Mahasiswa Terhadap Pengelolaan Pembelajaran Online Dimasa Pandemi Covic-19. Jurnal Ilmu Pendidikan. 1(1), 19-27.

Winarti, T., Masriani, \& Hadi, L. (2017). Pengaruh Model Role Playing Terhadap Minat Dan Hasil Belajar Siswa Pada Materi Ikatan Kimia. Jurnal Pendidikan dan Pembelajaran Untan. 6(9).

Yulia, S. R, \& Ramli. (2019). Analisis Kebutuhan Pengembangan Handout Berbasis STEM Terhadap Pembelajaran Fisika dalam Menghadapi Era Revolusi Industri 4.0. Jurnal Penelitian Pembelajaran Fisika. 5(1), 42-48. 